\title{
Pengaruh Pola Gerak Elektroda Pada Proses Pengelasan Baja St 37 Dengan Las Smaw Terhadap Sudut Distorsi dan Kekuatan Tarik
}

\author{
Puguh Budi Santosa ${ }^{1)}$, Wahono ${ }^{2)}$, Abdul Qolik ${ }^{2)}$ \\ ${ }^{1,2,3}$ Program Studi S1 Pendidikan Teknik Mesin Jurusan Teknik Mesin \\ ${ }^{1,2,3}$ Fakultas Teknik Universitas Negeri Malang \\ 1,2,3 Jalan Semarang No. 5, Malang 65145 \\ Email:puguhbs1@gmail.com
}

\begin{abstract}
Abstrak: Tujuan dari penelitian ini untuk mengetahui bagaimana sudut distorsi dan kekuatan tarik serta hubungan keduanya hasil pengelasan SMAW dengan variasi pola gerak elektroda. Metode penelitian ini menggunakan eksperimen dengan pendekatan kuantitatif. Hasil penelitian diperoleh: (1)sudut distorsi dengan pola gerak elektroda melingkar sebesar 1,6o, (2)pola gerak elektroda zig-zag 1,4o, (3)pola gerak elektroda C 2,8o. (4)pada spesimen raw material diperoleh kekuatan tarik sebesar 19,36 kgf/mm2. (5)Nilai kekuatan tarik pada pola gerak elektroda melingkar 21,714 kgf/mm2, (6)pola gerak elektroda zig-zag 22,528 kgf/mm2, (7)pola gerak elektroda C 23,134 kgf/mm2.
\end{abstract}

Kata Kunci: Pola Gerak Elektroda, Pengelasan SMAW, Sudut Distorsi, Kekuatan Tarik.

Berdasarkan definisi dari Deutche Industri Normen (DIN) las adalah ikatan metalurgi pada sambungan logam atau logam paduan yang dilaksanakan pada keadaan lumer atau cair. Dari definisi tersebut dapat dijabarkan lebih lanjut bahwa las adalah sambungan setempat dari beberapa batang logam dengan menggunakan energi panas (Wiryosumarto, 1996:1).

Pengelasan SMAW adalah pengelasan lebur dimana penyatuan logam dicapai dengan menggunakan panas dari busur listrik. Pada saat proses pengelasan terjadi perbedaan temperatur yang sangat besar didaerah busur las dengan daerah sekitar logam induk akan menimbulkan distribusi temperatur atau panas yang tidak merata, sehingga menyebabkan terjadinya pencairan, pembekuan, pengembangan, dan penyusutan termal didaerah sambungan dan sekitarnya pada suatu konstruksi las yang juga tidak merata yang mendorong terjadinya gaya eksentris pada penampang melintang logam las.

Semakin besar masukan panas dan arus saat pengelasan yang diterima akan mengakibatkan semakin besar regangan thermal (pengembangan dan penyusutan) tidak merata yang terjadi pada sambungan pengelasan dan sekitarnya. Pada konstruksi las yang dibiarkan bebas bergerak tanpa mendapat gaya atau beban dari luar, regangan thermal yang tersisa setelah suhu lasan mencapai temperatur kamar atau mendingin disebut sebagai distorsi las. Distorsi didefinisakan sebagai setiap perubahan dari bentuk atau kontur yang diinginkan. Demikian untuk sambungan tumpul dibedakan menjadi enam macam distorsi las bentuk distorsi tersebut adalah : penyusutan melintang (transverse shrinkage) yang muncul tegak lurus terhadap garis lurus, penyusutan memanjang (longitudinal shrinkage) yang muncul paralel terhadap garis las, perubahan anguler berupa rotasi disekitar garis las, perubahan bentuk sudut, deformasi memanjang, deformasi berombak (Huda, 2013).

Pencairan logam saat pengelasan menyebabkan adanya perubahan fasa logam dari padat hingga mencair. Ketika logam cair mulai membeku akibat pendinginan cepat, maka akan terjadi perubahan struktur mikro dalam deposit logam dan logam dasar yang terkena pengaruh panas atau daerah pengaruh panas (Heat affected zone/HAZ). Daerah pengaruh panas atau HAZ adalah logam dasar yang bersebelahan atau kanan kiri dari logam las yang selama proses pengelasan mengalami siklus termal pemanasan dan pendinginan cepat sehingga daerah ini yang kritis dari sambungan las (Habibi, 2015). Akibat dari pemanasan, pendinginan cepat dan berubahnya struktur mikro menyebabkan berubahnya sifat mekanis yang meliputi kekenyalan, kekuatan, kekerasan, keliatan, kegetasan, dan ketahanan ausnya.

Penelitian sebelumnya, Agus Duniawan (2015) telah melakukan penelitian mengenai Pengaruh Gerak Elektroda dan Posisi Pengelasan terhadap Uji Kekerasan dari Hasil Las Baja SSC 41. Hasil penelitiannya, Gerakan Elektroda memberikan pengaruh yang nyata terhadap nilai kekerasan pada daerah pengaruh panas(HAZ), di mana gerakan elektroda pola $\mathrm{C}$ memberikan nilai kekerasan yang lebih tinggi di bandingkan dengan gerakan elektroda Zig-zag dan melingkar. Sedangkan Posisi pengelasan memberikan pengaruh yang nyata terhadap nilai kekerasan pada daerah pengaruh panas( $H A Z$ ),dimana posisi pengelasan atas kepala memberikan nilai kekerasan yang lebih tinggi dibandingkan dengan posisi pengelasan datar dan posisi vertikal. Sedangkan Nilai kekerasan Vikers tertinggi rata-rata $513,891 \mathrm{Kg} / \mathrm{mm}^{2}$ terdapat pada posisipengelasan atas kepala dan pada variabel gerakan elektroda pola C, sedangkan nilai kekerasan Vikers terendah rata-rata $441,348 \mathrm{~kg} / \mathrm{mm}^{2}$ terdapat pada posisi pengelasan datar dan pada gerakan elektroda pola zig-zag.

Penelitian sebelumnya peneliti hanya meneliti tentang Gerak Elektroda dan Posisi Pengelasan terhadap Uji Kekerasan dari Hasil Las Baja SSC 41 sedangkan pada penelitian ini meniliti tentang pola gerak elektroda terhadap sudut distorsi dan kekuatan 
tarik las smaw sebagai pembaruan sehingga penelitian ini memilih judul : "PENGARUH POLA GERAK ELEKTRODA PADA PROSES PENGELASAN BAJA ST 37 DENGAN LAS SMAW TERHADAP SUDUT DISTORSI DAN KEKUATAN TARIK".

\section{METODE PENELITIAN}

Metode penelitian adalah suatu cara yang digunakan dalam penelitian, sehingga pelaksanaan dan hasil penelitinan dapat dipertanggungjawabkan secara ilmiah. Menurut metodenya, penelitian ini merupakan penelitian eksperimental. Dalam penelitian eksperimental banyak digunkan pendekatan kuantitatif. Eksperimental di laksanakan di laboratorium dengan kondisi dan peralatan yang disesuaikan guna memperoleh data tentang pengaruh pola gerak elektroda pada proses pengelasan baja ST 37 dengan las smaw terhadap sudut distorsi dan kekuatan tarik.

Objek penelitian yang dipakai adalah baja karbon rendah ST 37. dengan komposisi kimia $\mathrm{C}=0,063 \%, \mathrm{Mn}=0,621 \%$, $\mathrm{P}=0,013 \%, \mathrm{~S}=0,006 \%, \mathrm{Si}=0,158 \%, \mathrm{Sn}=0,003 \%, \mathrm{Al}=0,024 \%, \mathrm{Cr}=0,037 \%, \mathrm{Cu}=0,039 \%, \mathrm{Ni}=0,025 \%, \mathrm{Nb}=0,0028 \%, \mathrm{~V}=0,0015 \%$, $\mathrm{Ca}=0,0009 \%, \mathrm{Mo}=0,010 \%, \mathrm{~W}=0,006 \%, \mathrm{~N}=0,010 \%, \mathrm{Ti}=0,001 \%, \mathrm{Co}=0,006 \%$ (PT TATALOGAM LESTARI).

Alat yang Digunakan adalah 1) Mesin las SMAW, 2) Mesin potong plat, 3) Alat bantu las : sikat baja, sarung tangan, palu, helm las, kostum welder lengkap, gerinda dan tang, 4) Alat perlengakapan kantor seperti : pensil, pen, dan kertas kosong, dan kertas uji, 5) Busur dan bavel untuk mengukur sudut distorsi, 6) Mesin penguji tarik UPM Merk Kai Wei Universal Testing Machine dengan beban maksimal 100.000 kg, 7) Kamera HP untuk dokumentasi.

\section{Diagram Alir Penelitian}

Diagram alir penelitian merupakan pedoman bagi penulis dalam melakukan penelitian sesuai dengan yang direncanakan. Diagram alir penelitian dapat dilihat pada gambar 1

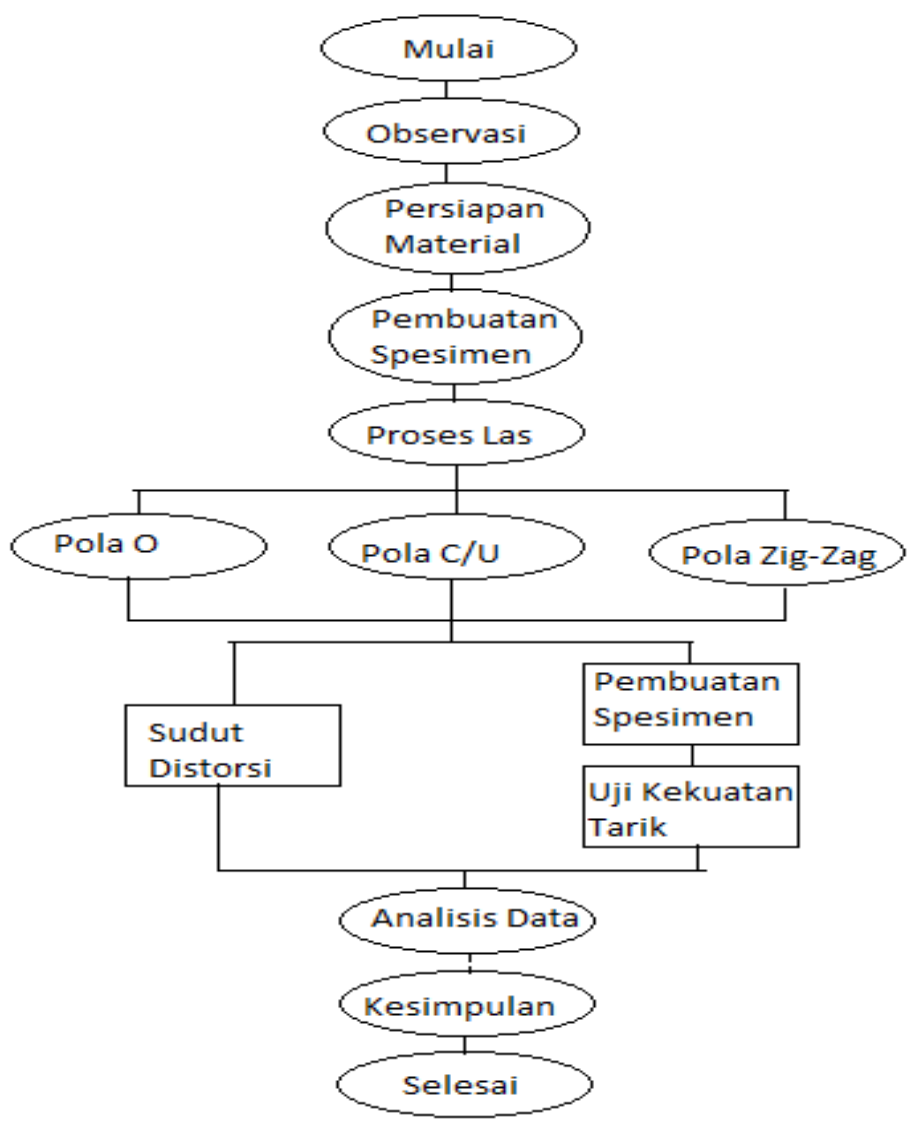

Gambar 1. Diagram Alir Penelitian 


\section{Bentuk Spesimen}

Benda kerja kemudian dibentuk menjadi spesimen uji tarik sesuai dengan ASTM E8/E8M-09. Pembentukan spesimen ini menggunakan mesin skrap dan mesin frais.
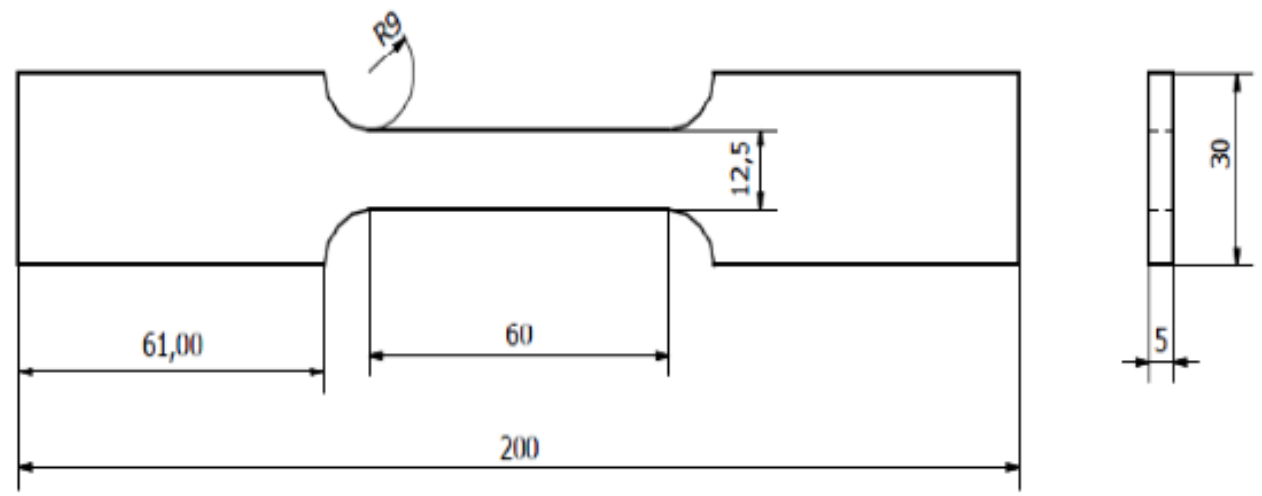

Gambar 2. Spesimen Uji Tarik ASTM E8/E8M-09

\section{Analisis Data}

Teknik analisis data yang di-gunakan dalam penelitian ini adalah teknik analisis statistik deksriptif untuk mendeskripsikan rata-rata data yang dihasilkan dari tiap varian.

\section{HASIL DAN PEMBAHASAN}

\section{Sudut Distorsi Pada Hasil Pengelasan Baja ST 37 dengan Las SMAW Menggunakan Pola Gerak Elektroda Melingkar}

Berdasarkan hasil pengelasan dengan pola gerak elektroda melingkar didapatkan hasil sudut distorsi baja ST 37 dalam bentuk angka dapat dilihat pada tabel dibawah ini.

Tabel 5.1 Hasil pengujian Sudut Distorsi Pada Hasil Pengelasan Baja ST 37 dengan Las SMAW Menggunakan Pola Gerak Elektroda Melingkar

\begin{tabular}{rc}
\hline Pola Gerak Elektroda Melingkar & Sudut Distorsi \\
\hline 1 & 2 \\
\hline 2 & 2 \\
\hline 3 & 1,5 \\
\hline 4 & 1,5 \\
\hline 5 & 1 \\
\hline Rata-rata & 1,6
\end{tabular}




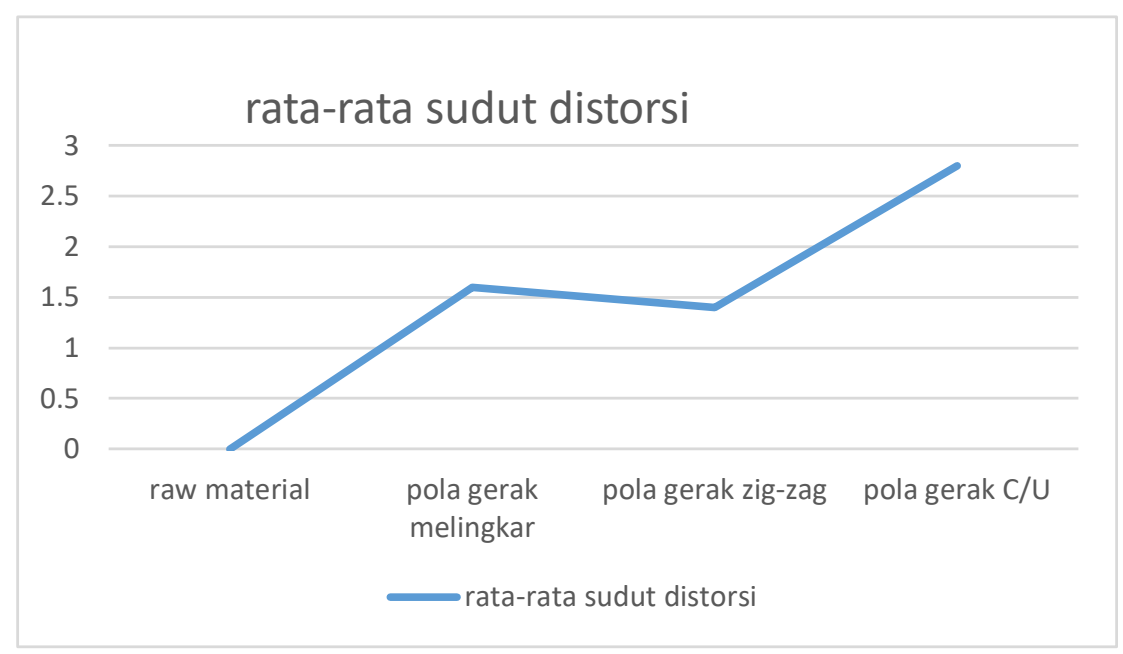

Gambar 5.1 Rata-rata Sudut Distorsi dengan Variasi Pola Gerak Elektroda

Dari tabel 5.1 dan gambar 5.1 dapat diketahui rerata hasil pengujian sudut distorsi pada hasil pengelasan baja ST 37 dengan las $S M A W$ dengan pola gerak elektroda melingkar yaitu sebesar $1,6^{\circ}$.

Pada penggunaan pola gerak elektroda melingkar ini mengalami kenaikan sudut distorsi. Pola gerak elektroda melingkar ini mengalami kenaikan heat input. Dimana penurunan masukan panas semakin kecil akan memperkecil terjadinya distorsi arah longitudinal maupun distorsi arah transversal (Wibowo : 2016). Pada pola gerak elektroda melingkar ini pada mengalami perbedaan penyusutan. Dimana bagian atas spesimen sambungan las mengalami penyusutan yang besar sedang pada bagian bawah spesimen sambungan mengalami penyusutan yang kecil sehingga menyebabkan distorsi sudut yang besar (Huda : 2013). Pada pola gerak elektroda melingkar ini memiliki laju pendingingan yang besar dan dimensi bahan yang kecil. Dimana semakain besar laju pendinginan dan semakin kecil dimensi bahannya akan semakin besar sudut distorsinya (Wiryosumarto, 1996). Pada pola gerak elektroda melingkar terjadi perbedaan temperatur antara permukaan yang dilas dan sebaliknya. Dimana perubahan sudut disababkan karena adanya perbedaan temperatur antara permukaan yang dilas dan permukaan sebaliknya (Wiryosumarto, 1996).

\section{Sudut Distorsi Pada Hasil Pengelasan Baja ST 37 dengan Las SMAW Menggunakan Pola Gerak Elektroda Zi-zag}

Berdasarkan hasil pengelasan dengan pola gerak elektroda zig-zag didapatkan hasil sudut distorsi baja ST 37 dalam bentuk angka dapat dilihat pada tabel dibawah ini.

Tabel 5.2 Hasil pengujian Sudut Distorsi Pada Hasil Pengelasan Baja ST 37 dengan Las SMAW Menggunakan Pola Gerak Elektroda Zig-zag

\begin{tabular}{cc}
\hline Pola Gerak Elektroda Zig-zag & Sudut Distorsi \\
\hline 1 & 1 \\
\hline 2 & 1 \\
\hline 3 & 2 \\
\hline 4 & 2 \\
\hline 5 & 1 \\
\hline Rata-rata & 1,4 \\
\hline
\end{tabular}




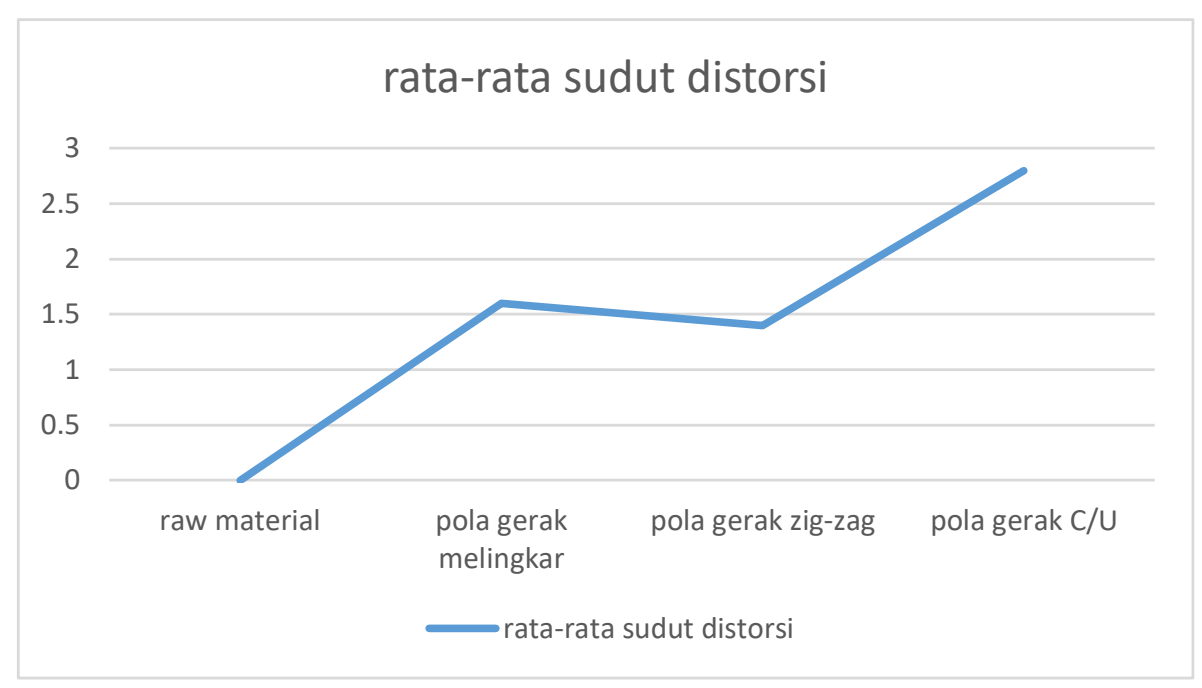

Gambar 5.2 Rata-rata Sudut Distorsi dengan Variasi Pola Gerak Elektroda

Dari tabel 5.2 dan gambar 5.2 dapat diketahui rerata hasil pengujian sudut distorsi pada hasil pengelasan baja ST 37 dengan las $S M A W$ dengan pola gerak elektroda zig-zag yaitu sebesar $1,4^{\circ}$.

Pada penggunaan pola gerak elektroda zig-zag ini mengalami penurunan sudut distorsi. Pola gerak elektroda melingkar ini mengalami kenaikan heat input. Dimana penurunan masukan panas semakin kecil akan memperkecil terjadinya distorsi arah longitudinal maupun distorsi arah transversal (Wibowo : 2016). Pada pola gerak elektroda zig-zag ini pada mengalami perbedaan penyusutan. Dimana bagian atas spesimen sambungan las mengalami penyusutan yang besar sedang pada bagian bawah spesimen sambungan mengalami penyusutan yang kecil sehingga menyebabkan distorsi sudut yang besar (Huda : 2013). Pada pola gerak elektroda zig-zag ini memiliki laju pendingingan yang besar dan dimensi bahan yang kecil. Dimana semakain besar laju pendinginan dan semakin kecil dimensi bahannya akan semakin besar sudut distorsinya (Wiryosumarto, 1996). Pada pola gerak elektroda Zig-zag terjadi perbedaan temperatur antara permukaan yang dilas dan sebaliknya. Dimana perubahan sudut disababkan karena adanya perbedaan temperatur antara permukaan yang dilas dan permukaan sebaliknya (Wiryosumarto, 1996).

\section{Sudut Distorsi Pada Hasil Pengelasan Baja ST 37 dengan Las SMAW Menggunakan Pola Gerak Elektroda C}

Berdasarkan hasil pengelasan dengan pola gerak elektroda C didapatkan hasil sudut distorsi baja ST 37 dalam bentuk angka dapat dilihat pada tabel dibawah ini.

Tabel 5.3 Hasil pengujian Sudut Distorsi Pada Hasil Pengelasan Baja ST 37 dengan Las SMAW Menggunakan Pola Gerak Elektroda C Pola Gerak Elektroda C Sudut Distorsi

\begin{tabular}{rl}
\hline 1 & 2 \\
\hline 2 & 3 \\
\hline 3 & 3 \\
\hline 4 & 2 \\
\hline 5 & 4 \\
\hline Rata-rata & 2,8
\end{tabular}




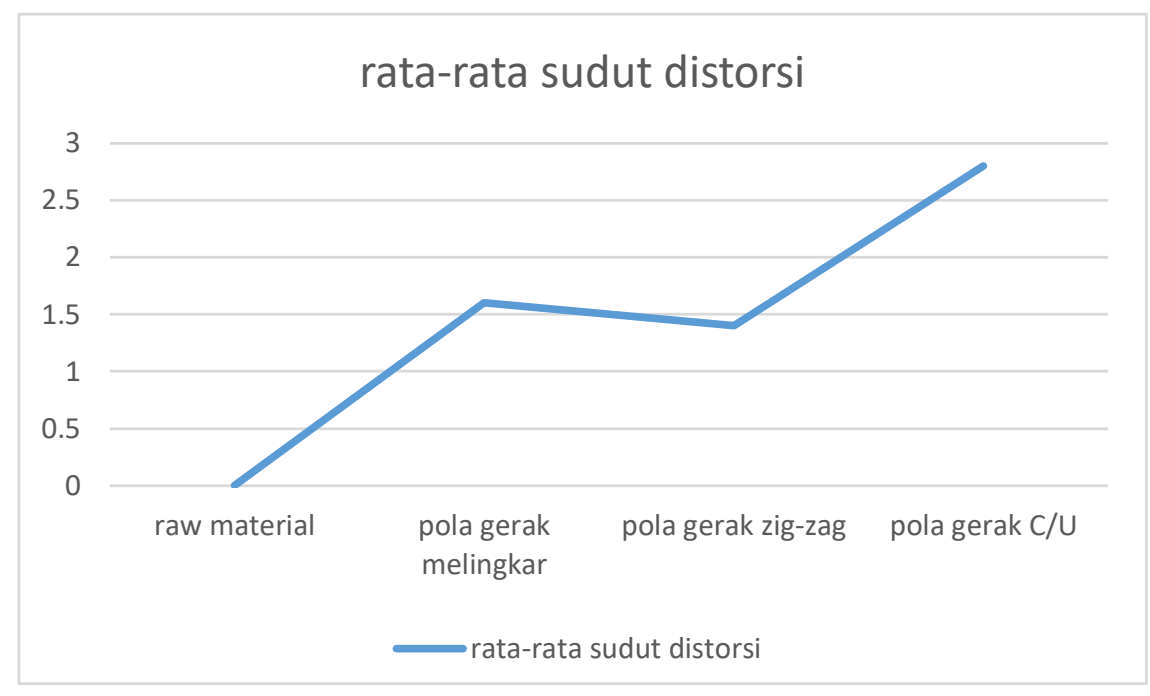

Gambar 5.3 Rata-rata Sudut Distorsi dengan Variasi Pola Gerak Elektroda

Dari tabel 5.3 dapat diketahui rerata hasil pengujian sudut distorsi pada hasil pengelasan baja ST 37 dengan las SMAW dengan pola gerak elektroda $\mathrm{C}$ yaitu sebesar $2,8^{\circ}$.

Pola gerak elektroda $\mathrm{C}$ mempunyai sudut distorsi yang tinggi dibandingkan dengan pola gerak elektroda zig-zag dan pola gerak elektroda melingkar dikarenakan bidang kontak dari ujung elektroda ke logam induk lebih besar sehingga temperatur puncak daerah HAZ lebih tinggi akibatnya laju pendingan lebih besar. Pada penggunaan pola gerak elektroda $\mathrm{C}$ ini memberi masukan panas yang lebih besar dibandingkan pola gerak zig-zag dan melingkar (Duniawan : 2015). Dimana masukan panas semakin tinggi akan memperbesar terjadinya distorsi arah langitudinal maupun distorsi arah transversal (Wibowo : 2016). Pada pola gerak elektroda $\mathrm{C}$ ini pada mengalami perbedaan penyusutan. Dimana bagian atas spesimen sambungan las mengalami penyusutan yang besar sedang pada bagian bawah spesimen sambungan mengalami penyusutan yang kecil sehingga menyebabkan distorsi sudut yang besar (Huda : 2013). Pada pola gerak elektroda C terjadi perbedaan temperatur antara permukaan yang dilas dan sebaliknya. Dimana perubahan sudut disababkan karena adanya perbedaan temperatur antara permukaan yang dilas dan permukaan sebaliknya (Wiryosumarto, 1996).

Sehingga dapat disimpulkan pola gerak C memiliki masukan panas yang tinggi dan laju pendingan yang besar dimana masukan panas yang semakin tinggi dan laju pendinginan yang semakin besar menyebabkan sudut distorsi semakin tinggi.

\section{Kekuatan Tarik Ultimate Hasil Pengelasan Baja ST 37 dengan Las SMAW Menggunakan Pola Gerak Elektroda Melingkar}

Berdasarkan hasil pengujian tarik hasil pengelasan baja ST 37 dengan Las SMAW menggunakan pola gerak elektroda melingkar diperoleh angka kekuatan tarik baj ST 37 yang dapat dilihat pada tabel dibawah ini.

Tabel 5.4 Hasil Kekuatan Tarik Ultimate Hasil Pengelasan Baja ST 37 dengan Las SMAW Menggunakan Pola Gerak Elektroda Melingkar

Pola Gerak Elektroda Melingkar $\quad$ Kekuatan Tarik

\begin{tabular}{rc}
\hline 1 & 19,77 \\
\hline 2 & 19,97 \\
\hline 3 & 24,02 \\
\hline 4 & 20,47 \\
\hline 5 & 24,34 \\
\hline Rata-rata & 21,714 \\
\hline
\end{tabular}




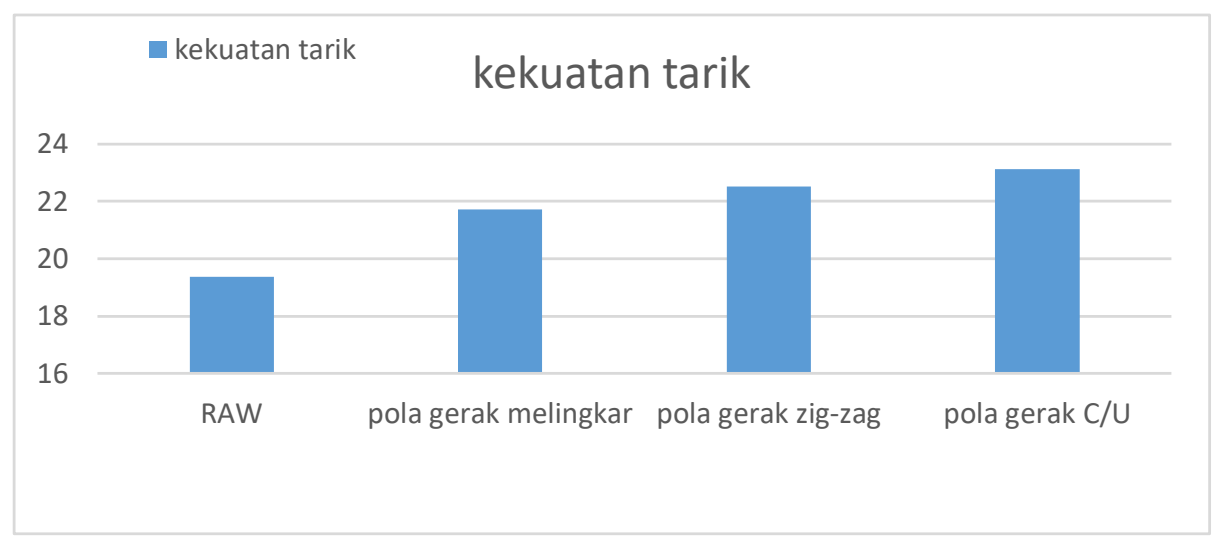

Gambar 5.4 Rata-rata Uji Tarik dengan Variasi Pola Gerak Elektroda

Dari tabel 5.4 dan gambar 5.5 dapat diketahui hasil rerata kekuatan tarik dengan pola gerak elektroda melingkar sebesar $21,714 \mathrm{kgf} / \mathrm{mm}^{2}$ terjadi peningkatan kekuatan tarik dibandingkan dengan spesimen tanpa perlakuan. Pada penggunaan pola gerak elektroda melingkar ini memiliki rerata kekuatan tarik meningkat dibandingkan spesimen tanpa perlakuan dikarenakan pertama kecepatan pengelasan yang besar dimana semakin besar kecepatan pengelasan maka kekuatan tarik yang diperoleh semakin besar (Setio:2014). Kedua penggunaan pola gerak elektroda melingkar ini memliki tingkat homogenitas dimana tingkat homogenitas yang tinggi maka gaya ikat antar atom juga tinggi sehingga kekuatan tariknya juga tinggi. ketiga Pada penggunaan pola gerak elektroda melingkar rerata kekuatan tarik saat patah masih sangat rendah dibandingkan pola gerak zig-zag dan pola gerak C ini di karenakan pelubaran las yang sangat dangkal. Pola gerak melingkar ini memilki hasil kekerasan sangat kecil dibandingkan pola gerak zig-zag dan C (Duniawan : 2015). Pada pola gerak elektroda melingkar memiliki dimensi bahan yang kecil kecepatan pendinginannya lebih besar jadi kekerasan besar dan kekuatan tarik besar. Dimana juga nilai kekerasan mempengaruhi hasil kekuatan tarik dimana hasil kekuatan tarik semakin besar nilai kekerasan semakin besar demikian sebaliknya semakin kecil kekuatan tarik nilai hasil kekerasan juga kecil (wibowo : 2016).

\section{Kekuatan Tarik Ultimate Hasil Pengelasan Baja ST 37 dengan Las SMAW Menggunakan Pola Gerak Elektroda Zig-zag}

Berdasarkan hasil pengujian tarik hasil pengelasan baja ST 37 dengan Las SMAW menggunakan pola gerak elektroda Zigzag diperoleh angka kekuatan tarik baj ST 37 yang dapat dilihat pada tabel dibawah ini.

Tabel 5.5 Hasil Kekuatan Tarik Ultimate Hasil Pengelasan Baja ST 37 dengan Las SMAW Menggunakan Pola Gerak Elektroda Zig-zag Pola Gerak Elektroda Zig-zag Kekuatan Tarik

\begin{tabular}{rc}
\hline 1 & 20,23 \\
\hline 2 & 24,33 \\
\hline 3 & 24,60 \\
4 & 18,66 \\
\hline 5 & 24,82 \\
\hline Rata-rata & 22,528 \\
\hline
\end{tabular}




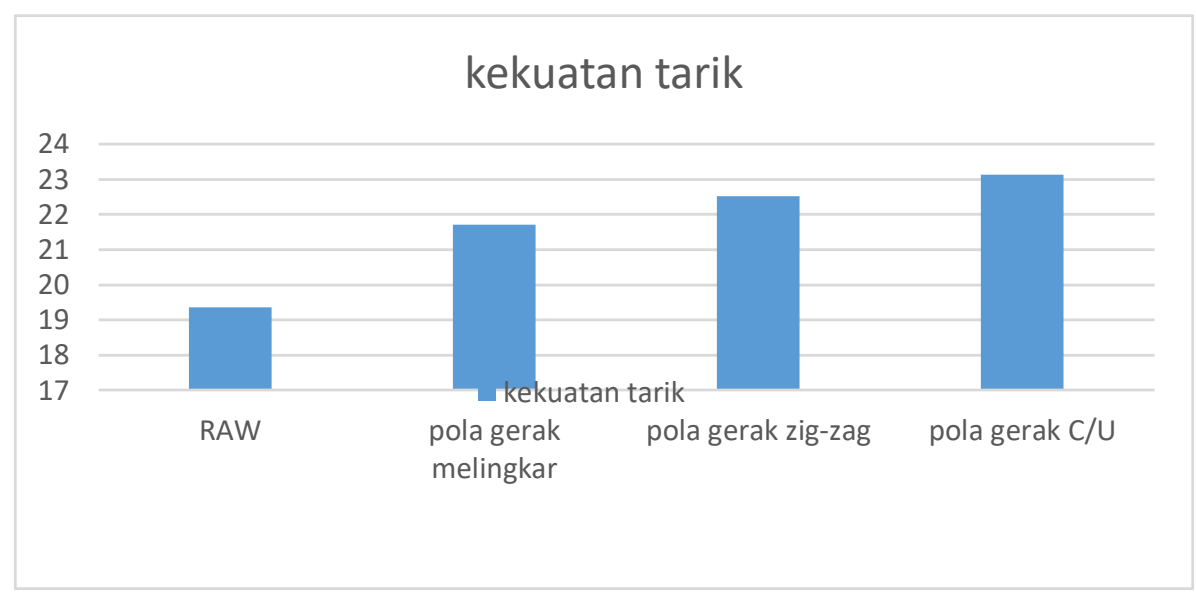

Gambar 5.5 Rata-rata uji tarik dengan Variasi Pola Gerak Elektroda

Dari tabel 5.5 dan gambar 5.5 dapat diketahui hasil rerata kekuatan tarik dengan pola gerak elektroda zig-zag sebesar $22,528 \mathrm{kgf} / \mathrm{mm}^{2}$ mengalami peningkatan kekuatan tarik jika dibandingkan dengan spesimen tanpa perlakuan dan spesimen pengelasan dengan pola gerak elektroda melingkar.

Penggunaan pola gerak elektroda zig-zag ini lebih baik daripada penggunaan elektroda melingkar karena pertama memiliki kekuatan tarik lebih besar dan kecepatan pengelasan yang besar dimana semakin besar kecepatan pengelasan maka kekuatan tarik yang diperoleh semakin besar (Setio:2014). Kedua penggunaan pola gerak elektroda zig-zag ini memliki tingkat homogenitas yang tinggi dibandingkan pola gerak elektroda melingkar dimana tingkat homogenitas yang tinggi maka gaya ikat antar atom juga tinggi sehingga kekuatan tariknya juga tinggi. Ketiga dimana nilai kekerasan spesimen pengelasan dengan pola gerak elektroda zig-zag lebih tinggi dibandingkan spesimen pengelasan dengan pola gerak elektroda melingkar (Duniawan : 2015). Pada pola gerak elektroda zig-zag memiliki dimensi bahan yang kecil kecepatan pendinginannya lebih besar jadi kekerasan besar dan kekuatan tarik besar. Dimana nilai kekerasan mempengaruhi hasil kekuatan tarik dimana hasil kekuatan tarik semakin besar nilai kekerasan semakin besar demikian sebaliknya semakin kecil kekuatan tarik nilai hasil kekerasan juga kecil (wibowo : 2016).

\section{Kekuatan Tarik Ultimate Hasil Pengelasan Baja ST 37 dengan Las SMAW Menggunakan Pola Gerak Elektroda C}

Berdasarkan hasil pengujian tarik hasil pengelasan baja ST 37 dengan Las SMAW menggunakan pola gerak elektroda C diperoleh angka kekuatan tarik baj ST 37 yang dapat dilihat pada tabel dibawah ini.

Tabel 5.6 Hasil Kekuatan Tarik Ultimate Hasil Pengelasan Baja ST 37 dengan Las SMAW Menggunakan Pola Gerak Elektroda C

Pola Gerak Elektroda C
Kekuatan Tarik

\begin{tabular}{rl}
\hline 1 & 24,94 \\
\hline 2 & 24,94 \\
\hline 3 & 20,34 \\
\hline 4 & 24,94 \\
\hline 5 & 20,51 \\
\hline Rata-rata & 23,134 \\
\hline
\end{tabular}




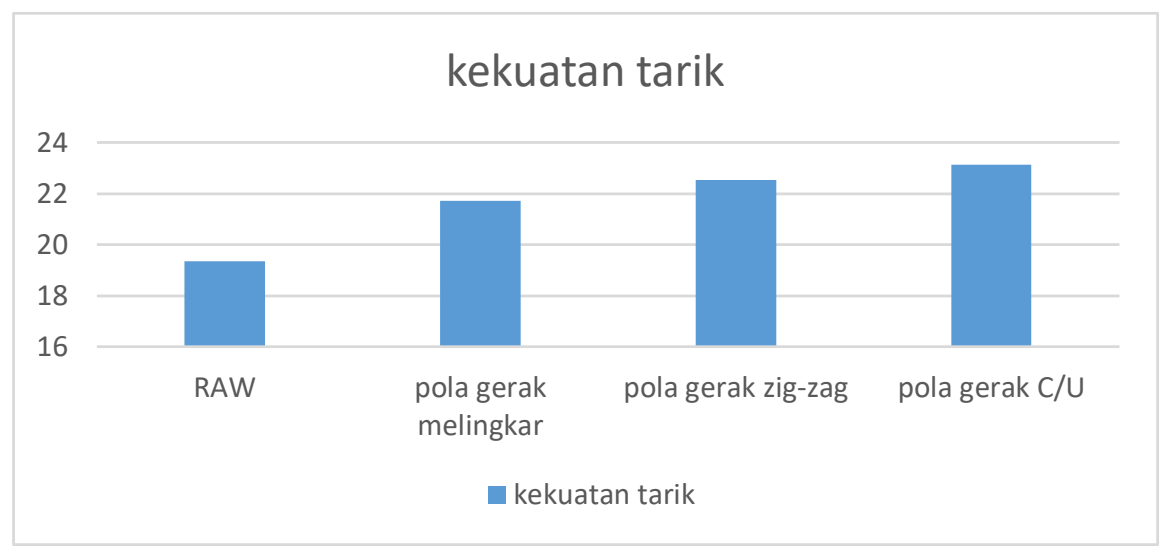

Gambar 5.6 Rata-rata uji tarik dengan Variasi Pola Gerak Elektroda

Dari tabel 5.6 gambar 5.6 dapat diketahui hasil rerata kekuatan tarik dengan pola gerak elektroda C sebesar 23,134 kgf/mm² mengalami peningkatan kekuatan tarik jika dibandingkan dengan spesimen tanpa perlakuan dan spesimen pengelasan dengan pola gerak elektroda melingkar dan zig-zag.

Penggunaan pola gerak elektroda $\mathrm{C}$ memiliki kekuatan tarik paling tinggi dibandingkan pola gerak elektroda zig-zag dan melingkar. Pertama pola gerak elektroda $\mathrm{C}$ memiliki kecepatan pengelasan yang besar dibandingkan pola gerak zig-zag dan melingkar dimana semakin besar kecepatan pengelasan maka kekuatan tarik yang diperoleh semakin besar (Setio:2014). Kedua penggunaan pola gerak elektroda $\mathrm{C}$ ini memliki tingkat homogenitas yang tinggi dibandingkan pola gerak elektroda melingkar dan zig-zag dimana tingkat homogenitas yang tinggi maka gaya ikat antar atom juga tinggi sehingga kekuatan tariknya juga tinggi. Ketiga dimana spesimen pengelasan dengan pola gerak leketroda $\mathrm{C}$ memberikan nilai kekerasan yang lebih tinggi dibandingkan spesimen dengan pola gerak elektroda zig-zag dan melingkar (Duniawan : 2015). Pada pola gerak elektroda C memiliki dimensi bahan yang kecil kecepatan

pendinginannya lebih besar jadi kekerasan besar dan kekuatan tarik besar. Dimana nilai kekerasan mempengaruhi hasil kekuatan tarik dimana hasil kekuatan tarik semakin besar nilai kekerasan semakin besar demikian sebaliknya semakin kecil kekuatan tarik nilai hasil kekerasan juga kecil (wibowo : 2016). Sehingga dapat disimpulkan bahwa nilai kekerasan semakin tinggi maka akan semakin tinggi pula nilai kekuatan tarik yang didapatkan.

\section{Posisi Perpatahan Spesimen Pengujian Tarik dari Hasil Pengelasan Baja ST 37 dengan Las SMAW dengan Pola Gerak Elektroda Melingkar}

Berdasarkan hasil pengujian tarik dari hasil pengelasan baja ST 37 dengan las SMAW dengan pola gerak elektroda melingkar didapatkan posisi perpatahan spesimen. Adapun hasil perpatahan dari spesimen dengan perlakuan pengelasan pola gerak elektroda melingkar adalah sebagai berikut :

Tabel 5.7 Posisi Perpatahan Spesimen Pengujian Tarik dari Hasil Pengelasan Baja ST 37 dengan Las SMAW dengan Pola Gerak Elektroda Melingkar

Pola gerak elektroda melingkar

\section{Perpatahan}

$17 \mathrm{~mm}$ disamping sambungan las

$15 \mathrm{~mm}$ disamping sambungan las

$16 \mathrm{~mm}$ disamping sambungan las

$14 \mathrm{~mm}$ disamping sambungan las

$11 \mathrm{~mm}$ disamping sambungan las 
Semua spesimen yang diuji secara eksperimental tidak putus pada daerah lasan seperti yang ditunjukan pada tabel. Daerah putus umumnya sekitar $30 \mathrm{~mm}$ dari daerah lasan, bentuk perpatahan yang terjadi adalah antara ulet dan getas, yang ditandai dengan pengecilan penampang (Hamdani : 2012). Hal ini disebabkan oleh penggunaan pola gerak elektroda dimana pola gerak elektroda mempengaruhi hail kekerasan pada daerah pengaruh panas(HAZ) (Duniawan : 2015) dan dipengaruhi juga oleh penggunaan parameter las yang baik dan juga faktor penggunaan elektroda jenis E7016. Jenis elektroda ini adalah elektroda basic yang baik digunakan untuk keperluan industri dan memiliki keunggulan dari segi kekuatan.

\section{Posisi Perpatahan Spesimen Pengujian Tarik dari Hasil Pengelasan Baja ST 37 dengan Las SMAW dengan Pola Gerak Elektroda Zig-zag}

Berdasarkan hasil pengujian tarik dari hasil pengelasan baja ST 37 dengan las SMAW dengan pola gerak elektroda zig-zag didapatkan posisi perpatahan spesimen. Adapun hasil perpatahan dari spesimen dengan perlakuan pengelasan pola gerak elektroda zig-zag adalah sebagai berikut :

Tabel 5.8 Posisi Perpatahan Spesimen Pengujian Tarik dari Hasil Pengelasan Baja ST 37 dengan Las SMAW dengan Pola Gerak Elektroda Zig-zag

\section{Pola gerak elektroda zig-zag}

\section{Perpatahan}

\section{1}

$16 \mathrm{~mm}$ disamping sambungan las

Pada sambungan las

Pada sambungan las

Pada sambungan las

$11 \mathrm{~mm}$

Pada spesimen dengan pola gerak elektroda zig-zag yang diuji secara eksperimental ada yang putus pada sambungan lasan atau logam las seperti yang ditunjukan pada tabel. Hal ini disebabkan pada saat pengelasan saat pengisian akar dan saat keeping kurang terisi sempurna dimana ini menyebabkan pengeroposan atau kurang terisinya sambungan pengelasan sehingga pada saat dilakukan uji tarik terjadi pada sambungan las. Pola zig-zag memiliki sifat patah ulet.

\section{Posisi Perpatahan Spesimen Pengujian Tarik dari Hasil Pengelasan Baja ST 37 dengan Las SMAW dengan Pola Gerak Elektroda C}

Berdasarkan hasil pengujian tarik dari hasil pengelasan baja ST 37 dengan las SMAW dengan pola gerak elektroda C didapatkan posisi perpatahan spesimen. Adapun hasil perpatahan dari spesimen dengan perlakuan pengelasan pola gerak elektroda $\mathrm{C}$ adalah sebagai berikut :

Tabel 5.9 Posisi Perpatahan Spesimen Pengujian Tarik dari Hasil Pengelasan Baja ST 37 dengan Las SMAW dengan Pola Gerak Elektroda C

\begin{tabular}{cc}
\hline Pola gerak elektroda C & Perpatahan \\
\hline $\mathbf{1}$ & $8 \mathrm{~mm}$ disamping sambungan las \\
\hline $\mathbf{2}$ & $15 \mathrm{~mm}$ disamping sambungan las \\
\hline $\mathbf{3}$ & $17 \mathrm{~mm}$ disamping sambungan las \\
\hline $\mathbf{4}$ & $12 \mathrm{~mm}$ disamping sambungan las \\
\hline $\mathbf{5}$ & $15 \mathrm{~mm}$ disamping sambungan las \\
\hline
\end{tabular}

Semua spesimen yang diuji secara eksperimental tidak putus pada daerah lasan seperti yang ditunjukan pada tabel. Daerah putus umumnya sekitar $30 \mathrm{~mm}$ dari daerah lasan, bentuk perpatahan yang terjadi adalah antara ulet dan getas, yang ditandai dengan pengecilan penampang (Hamdani : 2012). Hal ini disebabkan oleh penggunaan pola gerak elektroda dimana pola gerak elektroda mempengaruhi hail kekerasan pada daerah pengaruh panas(HAZ), dimana pola gerak $\mathrm{C}$ memberikan nilai kekerasan lebih tinggi dibandingkan dengan gerakan elektroda zig-zag dan melingkar (Duniawan : 2015) dan dipengaruhi juga 
oleh penggunaan parameter las yang baik dan juga faktor penggunaan elektroda jenis E7016. Jenis elektroda ini adalah elektroda basic yang baik digunakan untuk keperluan industri dan memiliki keunggulan dari segi kekuatan.

\section{Kesimpulan}

\section{SIMPULAN DAN SARAN}

Berdasarkan hasil pengujian dan analisa dari penelitian pengaruh pola gerak elektroda pada proses pengelasan baja st 37 dengan las SMAW terhadap sudut distorsi dan kekuatan tarik, maka dapat ditarik kesimpulan sebagai berikut :1)Hasil sudut distorsi pada hasil pengelasan baja ST 37 dengan las SMAW menggunakan pola gerak elektroda melingkar ialah sebesar $1,6^{\circ}$. 2)Hasil sudut distorsi pada hasil pengelasan baja ST 37 dengan las $S M A W$ menggunakan pola gerak elektroda zig-zag ialah sebesar $1,4^{\circ}$. 3)Hasil sudut distorsi pada hasil pengelasan baja ST 37 dengan las SMAW menggunakan pola gerak elektroda C ialah sebesar $2,8^{\circ}$. 4)Hasil kekuatan tarik ultimate hasil pengelasan baja ST 37 dengan las SMAW menggunakan pola gerak elektroda melingkar ialah sebesar 21,714 kgf/mm². 5)Hasil kekuatan tarik ultimate hasil pengelasan baja ST 37 dengan las $S M A W$ menggunakan pola gerak elektroda zig-zag ialah sebesar 22,528 kgf/mm². 6)Hasil kekuatan tarik ultimate hasil pengelasan baja ST 37 dengan las $S M A W$ menggunakan pola gerak elektroda $C$ ialah sebesar 23,134 kgf $/ \mathrm{mm}^{2}$. 7)Posisi perpatahan spesimen pengujian tarik dari hasil pengelasan baja ST 37 dengan las SMAW menggunakan pola gerak elektroda melingkar sebanyak 5 spesimen posisi perpatahannya disamping sambungan pengelasan atau di logam induk. 8)Posisi perpatahan spesimen pengujian tarik dari hasil pengelasan baja ST 37 dengan las SMAW menggunakan pola gerak elektroda zig-zag sebanyak 5 spesimen. 2 spesimen posisi perpatahannya disamping sambungan pengelasan atau di logam induk dan 3 spesimen posisi perpatahannya disambungan pengelasan. 9)Posisi perpatahan spesimen pengujian tarik dari hasil pengelasan baja ST 37 dengan las SMAW menggunakan pola gerak elektroda $\mathrm{C}$ sebanyak 5 spesimen posisi perpatahannya disamping sambungan pengelasan atau di logam induk.

Saran

Berdasarkan kesimpulan yang diperoleh, beberapa hal yang perlu ditindak lanjuti antara lain :

Bagi Peneliti Selanjutnya: (1)Dalam penelitian ini kualitas hasil pengelasan hanya diukur dari nilai sudut distorsi dan kekuatan tariknya. Untuk kelanjutan penelitian tentang pengaruh variasi pola gerak elektroda pada pengelasan $S M A W$ dapat dilihat sifat mekanik seperti kekerasan, kekuatan tekuk, impact, foto struktur mikro dan lain-lain untuk menghasilkan produk las yang lebih baik lagi dan mendapatkan hasil penelitian yang lebih lengkap. (2)Untuk mendapatkan hasil yang lebih teliti, perlu sampel spesimen yang lebih banyak lagi agar dapat hasil yang lebih teliti dan untuk menghindari faktor-faktor diluar variabel penelitian yang mempengaruhi kualitas hasil pengelasan.

Bagi Industri: Perlunya pemilihan pola gerak elektroda dan pemilihan elektroda pada pengelasan SMAW agar mendapatkan hasil sudut distorsi dan kekuatan tarik yang baik. Disarankan menggunakan pola gerak elektroda zig-zag dan menggunakan elektroda E7016 dengan diameter 2,6 mm dengan kuat arus 80 Ampere untuk mengelas plat baja ST 37 dengan tebal $5 \mathrm{~mm}$ untuk menghasilkan sambungan las dengan kekuatan tarik yang baik.

Bagi lembaga: Diasarankan dilengkapi perlengkapan-perlengkapan yang digunakan untuk membantu mahasiswa dalam melakukan penelitian, sehingga mahasiswa tidak perlu melakukan penelitian di lembaga lain.

\section{DAFTAR RUJUKAN}

ASTM Internasional (E8/E8M-09). Standart Test Methods for Tension Testing of Metalic Materials.2010. United States of America

Duniawan, A.2015. Pengaruh Gerak Elektroda dan Posisi Pengelasan terhadap Uji Kekerasan dari hasil Las Baja SSC 41. Jurnal Teknologi, 8 (2): 128-134. (Online), (http://jurtek.akprind.ac.id/sites/default/files/128_134_duniawan.pdf) diakses 26 september 2016.

Hamdani.2015. Pengaruh Masukan Panas proses Pengelasan Terhadap Sifat Mekanik Baja AISI 1045. Skripsi tidak diterbitkan. Lhokseumawe: Jurusan Teknik Mesin Politeknik Negeri Lhokseumawe.

Habibi, F.2015. Perlakuan Pemanasan awal Elektroda terhadap sifat Mekanik dan Fisik pada Daerah HAZ hasil pengelasan Baja Karbon ST 41. Prosiding SNST, ke-6 tahun 2015. (Online), (http://download.portalgaruda.org/article.php?article=352786\&val=5634\&title=PERLAKUAN\%20PEMANASAN\%20AWAL\%20 ELEKTRODA\%20TERHADAP\%20SIFAT\%20MEKANIK\%20DAN\%20FISIK\%20PADA\%20DAERAH\%20HAZ\%20HASIL \% 20PENGELASAN\%20BAJA\%20KARBON\%20ST\%2041) diakses 2 maret 2017.

Huda, S.2013. Analisa pengaruh Variasi arus dan Bentuk Kampuh pada Pengelasan Smaw terhadap Distorsi Sudut dan Kekuatan Tarik sambungan Butt-Join Baja AISI 4140. Jurnal Teknologi, 6 (2): 193-200. (Online), (http://jurtek.akprind.ac.id/sites/default/files/193200_huda.pdf) diakses 26 september 2016.

Setio, R.2014. Pengaruh Kecepatan Pengelasan dan Jenis Elektroda terhadap Kekuatan Tarik hasil pengelasan Smaw Baja ST 60. Skripsi tidak ditebitkan. Malang: Fakultas Teknik Universitas Brawijaya Malang.

Wibowo, H.2016. Analisa Heat Input Pengelasan terhadap Distorsi, Struktur Mikro dan Kekuatan Mekanis Baja A36. Jurnal Rekayasa Mesin, 7 (1): 5-12. (Online), (http://rekayasamesin.ub.ac.id/index.php/rm/article/download/280/259), diakses 27 maret 2017.

Wiryosumarto, H., 1996, Teknologi Pengelasan Logam, Erlangga, Jakarta. 